\title{
Egas Moniz: twice a double life
}

\section{Egas Moniz: uma dupla vida dupla}

José Manoel Bertolote

\begin{abstract}
Egas Moniz is credited with the discovery in 1927 of radioarteriography, for which he was, on three occasions, nominated for the Nobel Prize, and in all three denied the award. In 1949 he was awarded the Nobel Prize for Medicine for having designed leucotomy, a brain surgery to treat some forms of severe metal disorders. He was also an successful politician and accomplished statesman.
\end{abstract}

Keywords: Egas Moniz, radioarteriography, leucotomy, Nobel Prize, history.

RESUMO

Egas Moniz foi o inventor da radioarteriografia, em 1927. Devido a essa descoberta, seu nome foi, por três vezes, indicado para receber o Prêmio Nobel de Medicina e, nas três, não foi considerado merecedor do prêmio. Em 1949 finalmente ele recebeu o Nobel por ter concebido a leucotomia, um procedimento cirúrgico para "tratar certos transtornos mentais graves". Ele foi, ainda, um homem político e um estadista de sucesso.

Palavras-chave: Egas Moniz, radioarteriografia, leocotomia, Prêmio Nobel, história.

Egas Moniz (1874-1955) was the first Portuguese citizen to be awarded a Nobel Prize for Medicine, in 1949, in recognition for "the discovery of the therapeutic importance of prefrontal leucotomy in some psychosis"1, that resulted from research initiated in the early 1930s. By then, none of the presently most used psychiatric drugs and physical therapies had been discovered and, for some severe psychotic disorders, prefrontal leucotomy was indeed a "discovery".

However, little is said about what was perhaps the most important discovery of Egas Moniz, one for which on three occasions (1928, 1932 and 1937) he was nominated for the Nobel Prize, and not awarded. I refer to angiography.

In the first occasion the reason for not awarding was the limited experience which did not allowed an assessment of its real usefulness; in the second and third nominations the reason given for not awarding was that gas ventriculography was superior to angiography for the precise localization of brain tumors (!).

A book authored by João Lobo Antunes, current Professor of Neurosurgery at Lisbon Medical School and Director of Neurosurgery at St. Marta Hospital (Lisbon, Portugal - two institutions closely associated with Egas Moniz' career), and grand nephew of João Alfredo Lobo Antunes, the last and close assistant of Egas Moniz provides rich and well documented information and clarification about Egas Moniz life and career ${ }^{2}$.
He was a fascinating twice double character: a clinician/researcher and a politician, and a neurologist awarded a Nobel prize as a psychiatrist.

Egas Moniz obtained his basic academic degree in 1899. In 1901 he got a Doctor in Medicine degree with a thesis on The Sexual Life - Physiology; later in the same year he run for a teaching position at the Coimbra University with a thesis on The Sexual Life - Pathology.

In 1902 both theses were published as a single volume ${ }^{3}$ that quickly became a best seller (19 editions until 1933, when he refused to publish yet another edition on grounds of lack of interest in the topic and of time for revising the text), projecting him nationally as an expert in sexology.

In 1925 he stated trying different contrasts - among which lithium, strontium, sodium, ammonia bromides - to visualize brain circulation, as a means of improving the localizing of brain tumors, so far based purely on physical examination, first in animals and corpses and later in patients.

Finally, in June 28 1927, Egas Moniz and his assistant Pedro Almeida Lima, were able to visualize a pituitary tumor in a young man, using sodium iodine as an intravenous contrast. In July 07 1927, in a meeting of the Paris Neurological Association, Egas Moniz presented his findings to a public that included, among others, Babinski, Sicard and Clovis Vincent.

Upon his return from Paris, Egas Moniz made a presentation to his peers at Lisbon Medical School, and Reinaldo

Universidade Estadual Paulista Júlio de Mesquita Filho, Faculdade de Medicina de Botucatu, Botucatu SP, Brazil. 
dos Santos asked his opinion about the feasibility of the technique for the visualization of limb arteries. Later, Santos was probably the first one to perform a leg arteriography in vivo. However, the originality of the discovery of arteriography (radioarteriography, as Egas Moniz called it) belongs undeniable to Egas Moniz.

In the early 1930s, Egas Moniz started to focus his attention on the problem of mental disorders, or "the removal of malignant ideas rather than of malignant tumor", as it would be aptly described decades later ${ }^{4}$.

Until then, there mixed results of the removal of parts of the brain (usually the frontal lobe). Egas Moniz considered that it made no sense to "attack the cell bodies", and that it was preferable instead to interrupt their connections with cortical areas of interest only, hence leucotomy (cut of the white, in Greek).

Initially, he tried alcohol injection (already in use for trigeminal neuralgia) in the targeted area, with unsatisfactory results. He then designed a surgical instrument the leucotome - and in 12.11.1935 the first leucotomy was performed through bilateral trepanations at the level of the pre-frontal lobe.

In fact, Egas Moniz was not a surgeon himself since in 1935 he was already handicapped by severe artritis in both hands and could not conduct a delicate surgical intervention. The actual intervention was performed by his collaborator Almeida Lima, assisted by Ruy Lacerda, both neurosurgeons.

In the following year Egas Moniz published the first results in L'Encéphale ${ }^{5}$ and in a book ${ }^{6}$, acknowledging the collaboration of Almeida Lima and Lacerda, but his name only appeared as author. These two publication were the evidence used by the Nobel Committee to award in 1949 the Nobel Prize to Egas Moniz.
The new invention received a huge attention - thanks to Walter Freeman - and became widely used (and often misused) worldwide. Actually the initiative for the nomination of Egas Moniz to the Nobel Prize of Medicine for the invention of leucotomy was submitted by a group of Brazilian neurosurgeons and psychiatrists who attended the Congress of Neurosurgery in Lisbon, among whom Pacheco e Silva, Mattos Pimenta, Mário Yahn, Aníbal Silveira, Hélio Simões, Paulino Longo and Antonio Carlos Barreto.

Decades later, in view of severe side effects of ill-indicated prefrontal leucotomy, Egas Moniz and his discovery would become infamous and some people unduly asked the Nobel Committee to withdraw his award ${ }^{7}$.

In addition to his medical and scientific career, Egas Moniz was also an accomplished politician. Still in 1900 he was elected Member of the Parliament, being reelected several times and arrested also on several occasions. In 1918 he was appointed Head of a Delegation to Madrid in order to negotiate the reestablishment of diplomatic relation with the Holly See, interrupted a few years before. During 1018-1919 he was appointed Minister of Foreign Affairs; at the end of World War I he conducted the Portuguese Delegation to the Paris Conference to discuss war compensations to be paid by Germany to Portugal.

It is ironic that the Nobel Committee in three occasions did not consider the invention of radioarteriography worth the Prize and awarded it to an invention that history would demonstrated to worth much less than arteriography.

\section{Acknowledgement}

I am pleased to acknowledge Professor Arthur Schelp for his stimulus for the production of this article and Professor Celso Lafer for having facilitated useful bibliography.

\section{References}

1. Nobelprize.org. Nobel prize lists. 2015 [cited 2015 Jan 1]. Available from: www.nobelprize.org/nobel_prizes/lists/all/index.html

2. Antunes JL. Egas Moniz: uma biografia. Lisboa: Gradiva; 2010.

3. Egas Moniz AC. A vida sexual. Coimbra: França Amado;1902. 2 v.

4. Jefferson G. Professor Egas Moniz. Lancet. 1955;31: 1397.
5. Egas Moniz AC. Les premières tentatives opératoires dans le traitement de certaines psychoses. L'Encéphale. 1936; 31:1-29.

6. Egas Moniz AC. Tentatives opératoires dans le traitement de certaines psychoses. Paris: Masson; 1936.

7. Patients' kin want lobotomy Nobel withdrawn. (2005). Available from http://psychosurgeryorg.blogspot.it/2005_09_01_archive.html. 